\title{
Ecotoxicological risk assessment linked to infilling quarries with treated dredged seaport sediments
}

\author{
Yves Perrodin ${ }^{\mathrm{a}, *}$, Gilles Donguy ${ }^{\mathrm{a}}$, Christine Bazin ${ }^{\mathrm{b}}$, Laurence Volatier ${ }^{\mathrm{a}}$, Claude Durrieu ${ }^{\mathrm{a}}$, Sylvie Bony ${ }^{\mathrm{a}, \mathrm{c}}$, \\ Alain Devaux ${ }^{\mathrm{a}, \mathrm{c}}$, Mohammed Abdelghafour ${ }^{\mathrm{b}}$, Robert Moretto ${ }^{\mathrm{b}}$ \\ a Université de Lyon, ENTPE, CNRS, UMR 5023 LEHNA, 2 rue Maurice Audin, 69518 Vaulx-en-Velin, France \\ b INSAVALOR, 20 avenue Albert Einstein, 69621 Villeurbanne Cedex, France \\ c INRA, USC IGH, UMR LEHNA, 2, rue Maurice Audin, 69518 Vaulx-en-Velin, France
}

\begin{abstract}
The dredged sediments of polluted seaports now raise complex management problems since it is no longer possible to discharge them into the sea. This results in the need to manage them on land, raising other types of technical, economic and environmental problems. Regarding the technical and economic dimensions, traditional waste treatment methods have proved to be poorly adapted, due to very high costs and low absorbable volumes. In this context, filling quarries in coastal areas with treated sediments could represent an interesting alternative for these materials. Nevertheless, for the environmental dimension, it is necessary to demonstrate that this possibility is harmless to inland ecosystems. Consequently, a specific ecotoxicological risk assessment methodology has been formulated and tested on three sediments taken from seaboards of France, in view to providing an operational and usable tool for the prior validation of any operation to fill quarries with treated seaport sediments. This method incorporates the formulation of a global conceptual model of the scenario studied and the definition of protocols for each of its steps: the characterisation of exposures (based on a simulation of sediment deposit), the characterisation of effects (via the study of sediments ecotoxicity), and the final ecotoxicological risk assessment performed as a calculation of a risk quotient. It includes the implementation in parallel of two types of complementary approach: the "substances" approach derived from the European methodology for assessing new substances placed on the market, and the "matrix" approach which is similar to methods developed in France to assess ecological risks in other domains (waste management, polluted site management, ...). The application of this dual approach to the three sediments tested led to conclude with reliability that the project to deposit sediments " 1 " and " 2 " presented a low risk for the peripheral aquatic ecosystems while sediment " 3 " presented a high risk.
\end{abstract}

\section{Introduction}

Over the last 20 years, dredged seaport sediments have been subject to increasingly severe management procedures due to their contamination by the industrial, commercial, urban and tourist activities carried out in and around seaports (Andersen et al., 1998; Lau et al., 1993; MEEDDAT, 2008). The main families of pollutants concerned are heavy metals, Polycyclic Aromatic Hydrocarbons (PAHs) and Tributyltin (TBT), to which must be added a high chloride content leading to problems when these sediments are stored on land. The bioassays performed on these seaport sediments often reveal high ecotoxicity (Clément et al., 2009; Davoren et al., 2005a; MamindyPajany et al., 2009; Wong et al., 1995). Rarer studies also mention genotoxicity (Kocan et al., 1985; Srut et al., 2010). The current

\footnotetext{
* Corresponding author.

E-mail addresses: perrodin@entpe.fr, yperrodin@wanadoo.fr (Y. Perrodin).
}

figure for contaminated sediments located in seaports in France is high (about 10 million tonnes) and they cannot be dredged due to recent legislation prohibiting their discharge at sea (IFREMER, 2001). This leads to a new source of polluted materials for which no industrial method of treatment exists, since traditional treatment methods (incineration, landfilling, etc.) are poorly adapted to this type of material in both economic terms and those of absorbable volumes. In view to finding viable solutions for these materials, works have begun in many countries and in France in particular (Grosdemange et al., 2008). Different methods of reuse, e.g. use as aggregate/construction material, or use for artificial recharge of beaches or salt marshes, have been studied. Among them, one of the most promising alternative solutions under consideration is that of filling quarries located in coastal areas, as it is one of the best adapted both technically and economically, and it also provides sufficient capacities for managing the large quantities involved. Nonetheless, it was necessary to subject this solution to a research programme aimed at offering a specific ecological risk 
assessment methodology for validating the compatibility of each quarry fill project with its neighbouring inland ecosystems (terrestrial and aquatic) (SEDIGEST, 2011).

In this article, we first present the specific characteristics of dredged seaport sediments and the general approach to performing ecological risk assessments at international level, in view to formulating a specific method dedicated to the problem of filling coastal quarries with seaport sediments, and implementing it for three sediments taken from seaports in southern and western France.

\section{Specific characteristics of dredged seaport sediments}

The physicochemical composition of dredged seaport sediments is now becoming clearer due to the different characterisation campaigns carried out around the world. The main families of pollutants identified in these materials are heavy metals (Colacicco et al., 2010; Lepland et al., 2010; Romano et al., 2004), PAHs (AlebicJuretic, 2011; Gschwend and Hites, 1981; Romano et al., 2004; Simpson et al., 1996), and TBTs (Bhosle et al., 2006; Blanca, 2008; Langston et al., 1987; Saeki et al., 2007). However, reports of the fate and behaviour of these sediments when deposited on land, subject in particular to the action of rainwater, remain scarce and many grey areas persist (Chatain et al., 2009; Saeki et al., 2007). These areas include: (i) the effect of oxidation on sediments when they are transported on land; (ii) the effect of chlorides on the solubility of the mineral and organic pollutants present; (iii) the behaviour of the percolates seeping from the sediments into the soil located under the deposit, especially in the case of heterogeneous soils; (iv) the role of plants located on the surface of the deposit on pollutant transfers; (v) the bioavailability of sediment pollutants and its longterm evolution during storage; (vi) its toxicity for inland terrestrial and aquatic organisms under the exposure conditions concerned, the mixture of the pollutants present in mixture in the "marine sediment" matrix and in its emissions (percolates). In what follows, it will be necessary to take into account all these elements during the formulation of the ecological risk assessment methodology dedicated to managing the seaport sediments, in order to produce a reliable and robust tool.

\section{Methodological approach for the ecological risk assessment}

The first Ecological Risk Assessment (ERA) methodologies emerged at the beginning of the 1990s with dawning awareness of the risks liable to impact ecosystems exposed to substances of anthropic origin. In 1992, the United States EPA proposed a framework for the ecological risk assessment of contaminated industrial sites (US-EPA, 1992). Following a certain number of works, especially those of Suter (1993), this guide was improved to become "The Guidelines for Ecological Risk Assessment" (US EPA, 1998) and has become the reference regarding ERA (Hayet, 2006; Perrodin et al., 2011; Rivière, 1998). Since then, this guide has been revised by many countries and adapted to manage their polluted sites (CEAEQ 1998; Environment Agency of United Kingdoms, 2003; Liliburne and Phillips, 2011). In addition, methodologies have been formulated to evaluate ecological risks linked to other problems. Mention can be made of the methodology drawn up by the European Union to evaluate risks relating to chemical substances placed on the market (ECB, 2003; Environment Agency of United Kingdoms, 2003), of French studies on the assessment of ecotoxicological risks linked to dumping inland dredged sediments (CETMEF, 2001) and the assessment of the ecocompatibility of using wastes (Perrodin et al., 2000), and of the assessment of ecotoxicological risks linked to hospital effluents (Boillot et al., 2007; Emmanuel et al., 2005). Most ERA methods are implemented with four main phases: (1) the formulation of the problem, (2) the characterisation of exposures (3) the characterisation of effects, and lastly, (4) the characterisation of the risk itself (Fig. 1). It is noteworthy that the characterisation of exposures and that of effects are performed in parallel; however they are in constant interaction (Babut and Perrodin, 2001; Rivière, 1998).

\subsection{The formulation of the problem}

The problem formulation phase is fundamental. It comprises investigation and technical options, following which a highly precise plan of actions has to be established (identification of the data to be collected, the measurement and assessment techniques to be used, as well as the framework of interpretation) to carry out the subsequent phases of the ERA (Perrodin et al., 2011; Rivière, 1998; US EPA, 1998).

\subsection{The characterisation of exposures}

Exposure characterisation aims at determining the spatial-temporal contact between pollutants and target populations (US EPA, 1998). It includes the analysis of sources of pollutants, the transfer of the latter from their sources, and the distribution of pollutants in the environment. Exposure depends on both the concentrations of pollutants in the environment and the characteristics and behaviour of the target organisms. Finally, it takes into account the doses absorbed by target populations. This analysis can be performed by using theoretical models of pollutant transfer and/or pollutants and/or on the basis of experimental results (Perrodin et al., 2011).

This phase results in the determination of one or more values characterising exposure. In the case of a "substance-based" approach, the term "Predicted Environmental Concentration" (PEC) is used. It corresponds to the concentration to which organisms are exposed (in $\mathrm{mg} / \mathrm{l}$, for example). In the case of a "matrix" approach, the notion of percentage of polluted source matrix in the environment of the organisms is employed (the PEC is then expressed in \%). In both cases the parameter concerned is the concentration that can be expected in the environment following different inputs. Determining these values can prove complex, since account must be taken of a considerable number of phenomena liable to occur during transit via different pathways: dilution, evaporation, biodegradation, bio-accumulation, change of speciation of substances, the characteristics of the ecosystem, etc. Exposure can also be direct or indirect, short or long-term, or variable or invariable through time (RECORD, 2006; Rivière, 1998).

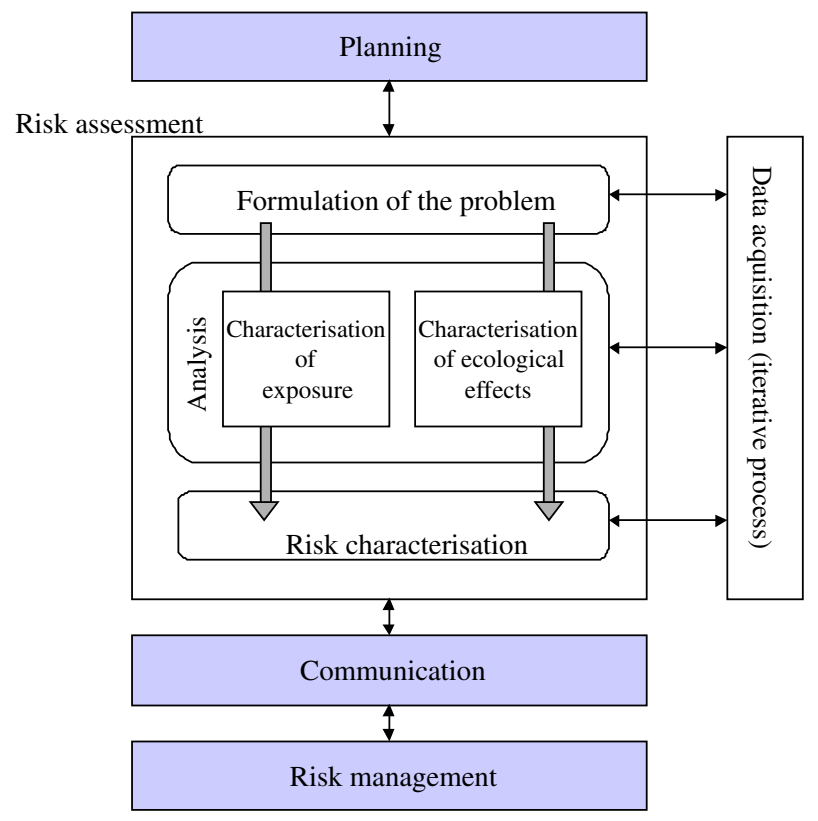

Fig. 1. General diagram of ecological risk assessment (US EPA, 1998). 


\subsection{The characterization of effects}

This phase entails defining to what extent the organisms of the target ecosystem are significantly sensitive to the pollutants to which they are exposed (Perrodin et al., 2011). This step is mainly based on biological approaches that include batteries of bioassays. A large number of batteries of bioassays have been proposed in the literature for different fields of study and matrixes. Mention can be made of those relating to: (1) substances (Davoren and Fogarty, 2004; Kim et al., 2007; Radix et al., 2000); (2) effluents (Andrén et al., 1998; Naudin et al., 1995; Persoone et al., 2003; Ren and Frymier, 2003); (3) sediments (Davoren et al., 2005b); (4) wastes (Clément et al., 1996; Isidori et al., 2003; Pandard et al., 2006; Rojícková-Padrtová et al., 1998); and (5) soils, sludges and composts (Juvonen et al., 2000; Schaefer, 2004). It results in the acquisition of different values of ecotoxicological effects as NOEC (No Observable Effect Concentration) or CE20 (Efficient Concentration on 20\% of the population), making it possible to calculate, after applying an extrapolation factor, the value of absence of significant effect on the whole of the target ecosystem. This value is commonly known as the PNEC (Predicted No Effect Concentration). Although the toxicity of a chemical mixture may be greater or lesser than predicted from toxicities of individual constituents of the mixture, a quotient addition approach assumes that toxicities are additive or approximately additive (US EPA, 1998). This assumption may be most applicable when the modes of actions of chemicals in a mixture are similar, but there is evidence that even with chemicals having dissimilar modes of action, additive or near-additive interactions are common (Altenburger et al., 2000; Bliss, 1939; Boillot and Perrodin, 2008; Feron and Groten, 2002; Hermens et al., 1984; Lin et al., 2004).

\subsection{The characterization of the risk itself}

To carry out this final phase of ecological risk assessment, there is a range of possible methods of variable complexity (Babut et al., 2002). The choice depends on the operational constraints and the available data. Rivière (1998) notes "the ecological risk can be expressed in various manners: qualitative (absence or not of risk), semi-quantitative (weak, average and high risk), and in probabilistic terms (the risk is $x \%)$ ". The method known as "the quotient" is the most widespread method for the semi-quantitative characterization of risks. This method consists in calculating the quotient which is equal to the "Predicted Environmental Concentration" (PEC) divided by the "Predicted No Effect Concentration" (PNEC). When the quotient value " $Q$ " is greater than 1 , the risk is considered as significant, and increasingly so as the quotient rises. Conversely, the further the quotient is below 1 , the more the risk is regarded as weak. The "probable non concentration effect" on an organism is, in practice, generally represented by NOEC or EC20 divided by an extrapolation factor (e.g. 10).

\section{Formulation of the specific risk assessment methodology}

\subsection{Formulation of the problem}

\subsubsection{Description of the scenario}

The aim of this description is to present the different ecosystems potentially in the vicinity of the seaport sediment deposit and the different exposure pathways concerned as exhaustively as possible to provide a full vision of the scenario (Fig. 2).

Regarding source $\mathrm{S} 1$, three samples of treated maritime sediments were selected to perform the programme. To do this, we first chose to work with relatively polluted sediments (Chatain et al., 2009) in order to obtain a response during the bioassays. In view to using the methodology in the future to validate landfill projects, less polluted sediments will be considered. The three sediments chosen taken from an Atlantic seaboard site (Port of Guilvinec) and from a Mediterranean seaboard site (Port of Toulon), were as follows:

- Sediment from the port of Toulon, dried and aired for 4 months (sediment 1),

- The fine fraction of the sediment from the port of Toulon, dried and aired for 4 months (sediment 2),

- Sediment from the port of Guilvinec limed and crushed (sediment 3).

Table 1 presents the substances chosen as risk tracers, given current knowledge of seaport sediments and their potential ecotoxicity.

Regarding the environmental targets to be taken into account, in the framework of the present article, it was first considered that runoff from the surface of the deposit was negligible (surface slope oriented inwards, peripheral drainage, etc.). It was then considered that the landfill project did not include a deposit surface vegetation project and that the local groundwater was not subject to risk, notably with respect to the production of drinking water. These choices led to narrowing the target environment to be studied to only that of C4 (aquatic environment) (other variants of the scenario will be the subject of further publications). The river (C4) located near the deposit therefore receives part of the deposit percolate flowing laterally on the peripheral soil. On the basis of a conservative assumption, we considered that the flow on the soil did not change the concentration of the substances transported in the percolate. Lateral flow (T3) was therefore the main pathway of pollution transfer to the river. The trophic levels and potential biological targets to be taken into account were primary producers (green algae, etc.), detritivores (bacteria, etc.), primary consumers (rotifers, crustaceans, etc.), and secondary consumers (fish, etc.).

Finally, source "S1" (maritime sediment), transfer "T3" (lateral flow) and target "C4" (river) composed the three main elements of the studied scenario. The spatial and numerical data of the latter were then set randomly for the needs of this study (Table 2), nonetheless with efforts being made to stick as closely as possible to the reality in-the-field.

It is noteworthy that the speciation of metal contaminants within the deposit can undergo modification, and that organic contaminants can be biodegraded. The biodegradation of PAHs, the main organic contaminants of the sediment, is a priori low given the probably anaerobic nature predominating within the deposit and the low dwell time during runoff on the soil. Whatever the case, this potential degradation mainly concerns compounds with low molecular weight. Furthermore, some pollutants are liable to bring about genotoxic effects (Devaux et al., 1998; Theodorakis, 2001; Würgler and Kramers, 1992). Although little is known at present about the additional risk this type of effect could generate, its potential consequences imply that they cannot be ignored and that they must be taken into account in risk assessment procedures applied to ecosystems.

\subsubsection{Selection of "assessment parameters" and formulation of the conceptual model}

The demands for preserving surface aquatic ecosystems can be summarised as follows: filling a terrestrial cavity with treated seaport sediments must not lead to short or long-term effects on the aquatic species of the river located nearby.

The assessment parameters are physicochemical (concentrations in sediment contaminants and percolates), physical (lateral runoff flow rates and river flow rates, dilution factor) and ecotoxicological (battery of bioassays performed for several trophic levels). Fig. 3 shows the conceptual model resulting from the choices made.

\subsection{Material and methods}

\subsubsection{Exposure characterisation}

The exposure level was based first on the water balance of the site, using the data of Table 2, and on the dilution of the percolate in the 


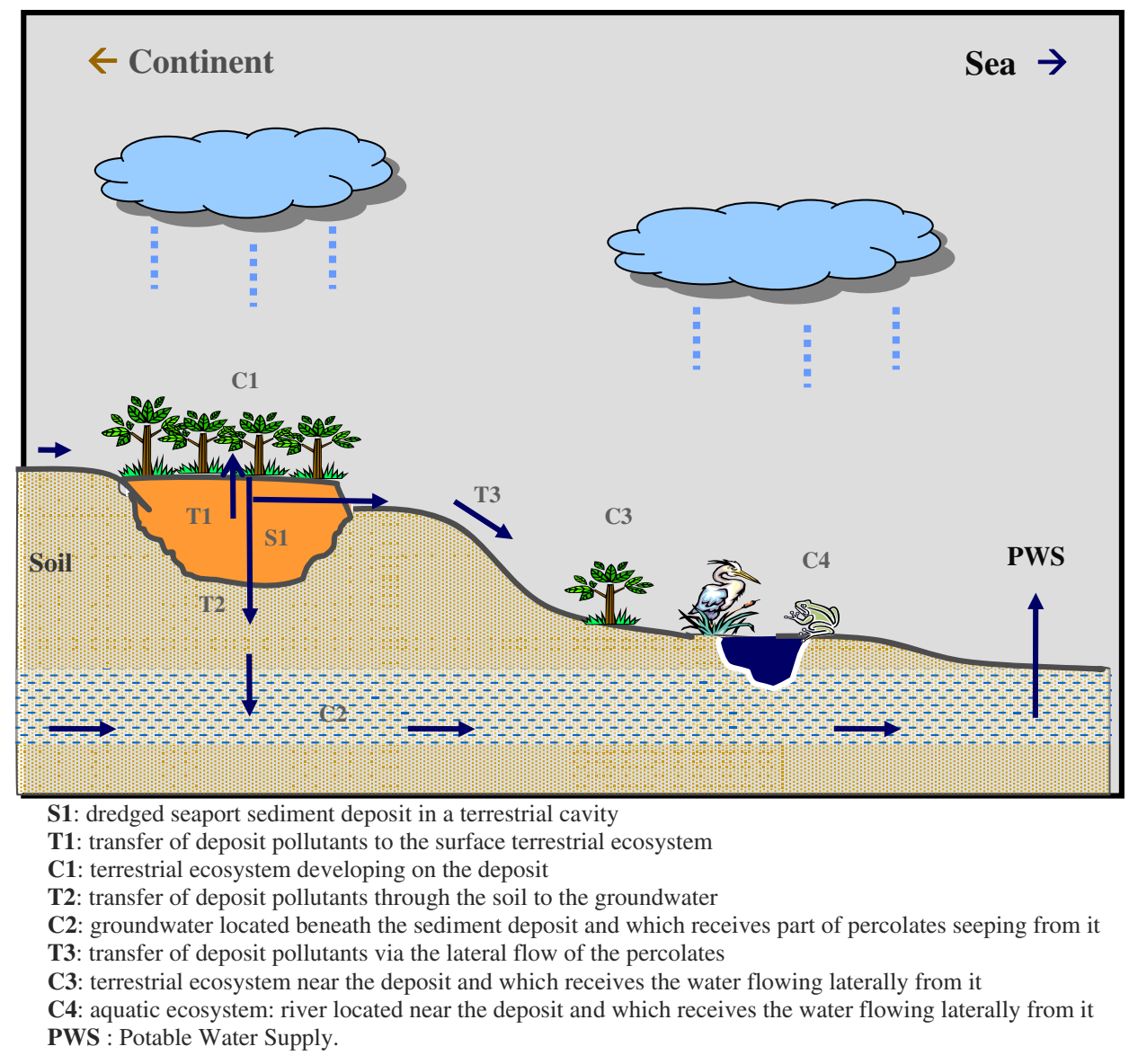

Fig. 2. Presentation of the studied scenario.

river during its low flow period, with the assumption that the runoff between the deposit and the river did not significantly reduce the flow of pollutants discharged by the deposit due to the nature of the soil, slope and the short distance between the deposit and the river. The ratio chosen for the distribution of the percolate, by taking into account the site data collected during the visit to several existing deposit sites, and the data available for similar scenarios (Perrodin et al., 2006), was 50\% for the groundwater and 50\% for the river.

In order to simulate the behaviour of the sediments deposit, and the fate of the pollutants, three lysimeters for the three treated sediments were then constituted. They were subjected to a controlled moisture regime lasting 18 months, with continued spraying (automated system) and sprinkling every $20 \mathrm{~min}$. These lysimeters were formed by rectangular aluminium tanks $(2.5 \mathrm{~m} \times 1.75 \mathrm{~m})$. A layer of sand was deposited at the bottom of the lysimeters, and a low point was installed in one of the angles of each one. It was covered with a polyolefin sealing geomembrane. A layer of draining material (gravel) $5 \mathrm{~cm}$ thick was deposited on the geomembrane and then covered with a protective geotextile to avoid any migration of the sediments

Table 1

Selected risk tracer substances-Selected criteria.

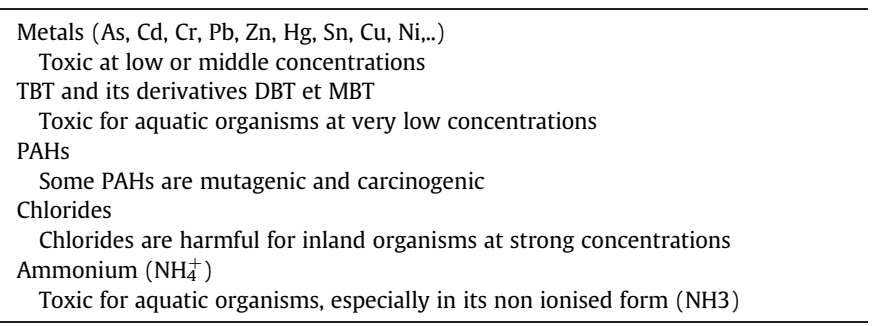

into the drainage layer. The sediment was finally placed over these sub-layers using a vibratory tamping machine to compact the sediment to Proctor density. The percolates were collected daily with a peristaltic pump, then stored automatically in a refrigerator while awaiting analysis. Regular measurements of $\mathrm{pH}$, conductivity, Redox potential and ammonium were performed.

Chemical analyses of the percolates of the 3 sediments were performed according to the following protocols:

- Metals: Standard NF EN ISO 11885,

- Chlorides: Standard ISO 10304-1 2007,

- PAHs: Standard ISO/WD/7981,

- Ammonium: Standard NF T 90-015-1,

- TBT: Standard ISO 17353.

The samples (about $900 \mathrm{~kg}$ per sediment) were taken from experimental sediment treatment sites. After homogenisation, they were divided into $100 \mathrm{l}$ drums and quickly transported to the laboratory. On arrival at the laboratory, they were subjected to sub-sampling to

Table 2

Spatial and numerical data of the studied scenario.

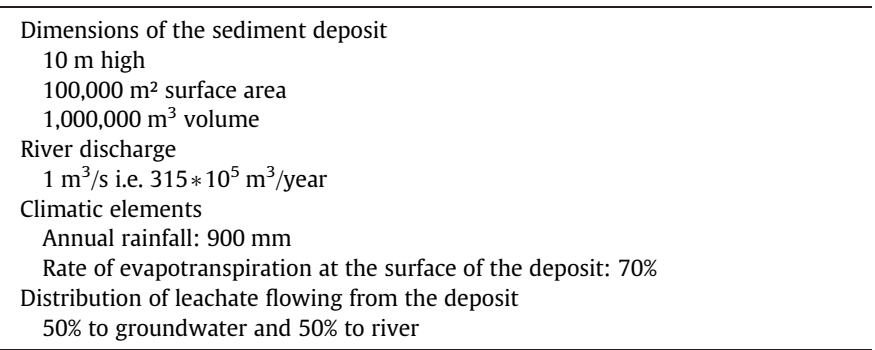




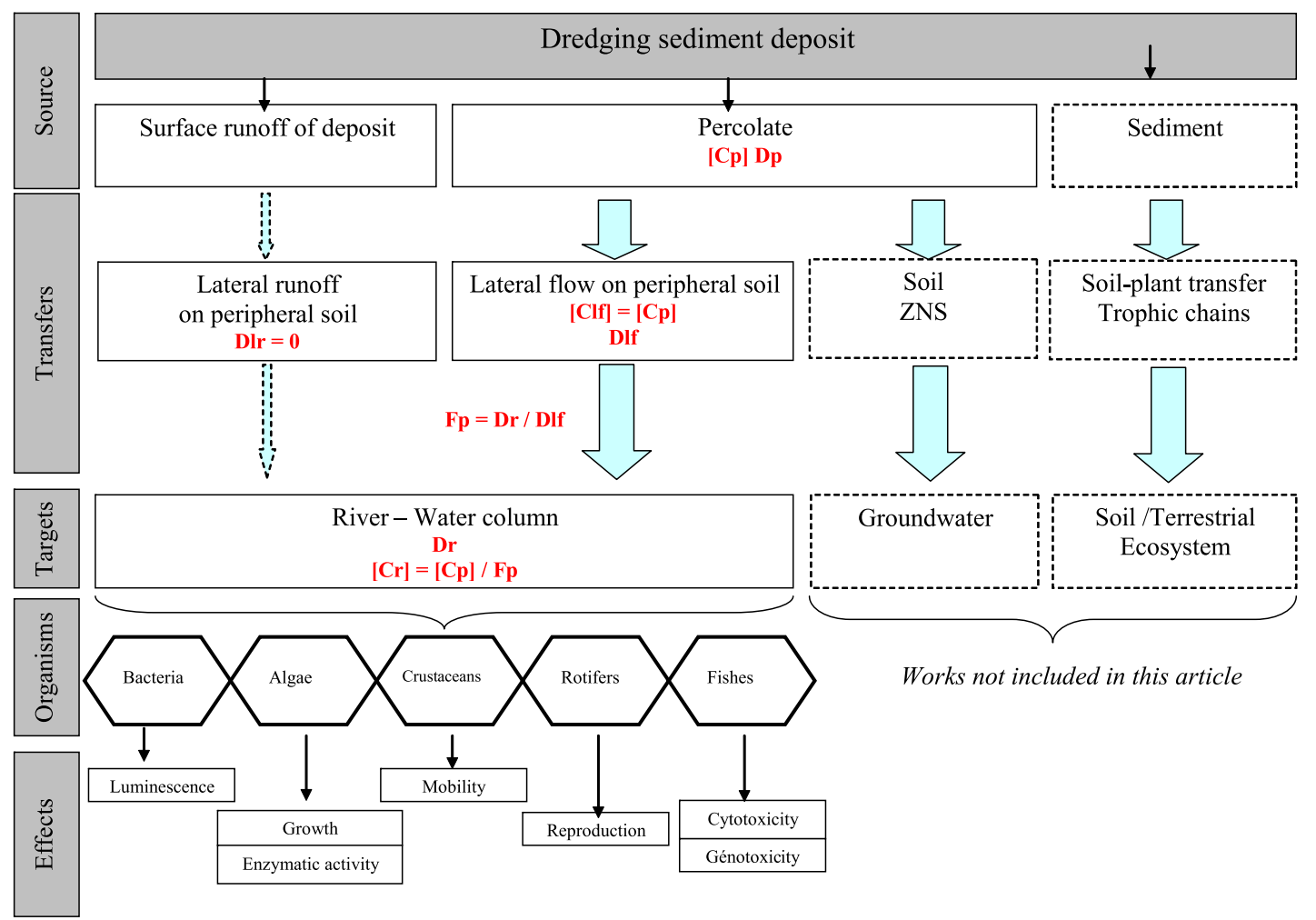

Cp : percolate Concentration, Dp : percolate Debit, Dlr : lateral runoff Debit, Clf :lateral flow Concentration, Dlf : lateral flow Debit, Fp : percolate dilution Factor, Dr : river Debit, $\mathrm{Cr}$ : river Concentration

Fig. 3. Conceptual model of the scenario studied.

prepare the samples required for each test and analysis. These operations were all performed as rapidly as possible after sampling. The resulting samples were then conserved in a cold chamber at $4{ }^{\circ} \mathrm{C}$.

\subsubsection{Effect characterisation}

The effects were characterised according to two complementary approaches: the "substances approach" and the "matrix approach". The "substances approach" consists in seeking in international databases the concentrations of each of the "risk tracer" substances with no effect on ecosystems (PNEC mg/l). The "matrix approach" consists in exposing organisms representative of the target ecosystem (bioassays) to a range of dilutions of the "matrix" responsible for the pollution, in this case the percolate discharged by the seaport sediment, so as to determine the no effect concentration of the latter for the target ecosystem (PNEC\%). For the "matrix approach", priority was given to selecting normalised (or standardised) bioassays. These bioassays are listed in Table 3. In conformity with the conclusions in the formulation of the problem, the battery of bioassays determined comprised tests representative of primary producers, detritivores, primary consumers and secondary consumers, as well as genotoxicity tests.

\subsubsection{Risk characterisation}

The "quotient method" can be applied to both the "substances approach" (pollutant concentrations) and the "matrix approach" (\% dilution of a complex matrix of pollutants).

In the case of the "substances approach", the objective is to determine the aquatic PNEC for each risk tracer, by consulting international databases and by taking the following approach: (i) if the PNEC values can be obtained from reference organisations, such as the US-EPA in the USA (US-EPA, 2011) or the INERIS in France (INERIS, 2011) for the substances considered, priority is given to these values, (ii) if certain PNEC values are not available, they have to be generated from ecotoxicological data available in international databases: the PNEC is then calculated according to the procedures of the TGD (ECB, 2003), which defines in particular the rules defining the extrapolation factors.

Table 3

Bioassays selected for the "matrix approach".

\begin{tabular}{|c|c|c|c|c|c|}
\hline Organisms & Duration & Effects & Parameters & Protocol & References \\
\hline Vibrio fischeri & $30 \mathrm{~min}$ & Luminescence & EC50 & Normalised & NF EN ISO 11348 \\
\hline Daphnia magna & $24 \mathrm{~h}$ & Mobility & EC50 & Normalised & NF EN ISO 6341 \\
\hline Brachionus calicyflorus & $48 \mathrm{~h}$ & Reproduction & EC20 & Normalised & NF T90-378 \\
\hline Pseudokirchneriella subcapitata & $72 \mathrm{~h}$ & Population growth & EC20 & Normalised & NF T90-375 \\
\hline Pseudokirchneriella subcapitata & $24 \mathrm{~h}$ & Enzymatic reaction speed (esterase) & LOEC & Standard & Barthet et al. (2003) \\
\hline Trout cell-lines (RTG-W1 and RTL-W1) & $24 \mathrm{~h}$ & Cytotoxicity & LOEC & Standard & Dayeh et al. (2003) \\
\hline Trout cell-lines (RTG-W1 and RTL-W1) & $24 \mathrm{~h}$ & $\begin{array}{l}\text { Genotoxicity } \\
\text { (Comet Assay) }\end{array}$ & DNA Damage & Standard & Kienzler et al. (2012) \\
\hline
\end{tabular}

EC50: Effect concentration for $50 \%$ of organisms. EC20: Effect concentration for $20 \%$ of organisms.

ISO: International Standard Organization. 
In the case of the "matrix approach", the TGD can also be used to adjust the value of the extrapolation factors as a function of the type and number of available test results.

\section{Results}

The approach described above was applied to the three sediments presented in the description of the scenario.

\subsection{Characterisation of exposures}

The results stemming from the numerical data of the scenario permit to calculate the lateral flow debit (Dlf) and the dilution factor of the percolate in the river (Fp):

- Dlf $=0.9 \mathrm{~m} /$ year $* 100,000 \mathrm{~m}^{2} * 0.3 * 0.5=0.135 * 10^{5} \mathrm{~m}^{3} /$ year

- $\mathrm{Fd}=315 * 10^{5} / 0.135 * 10^{5}=2333$ (i.e. $0.04 \%$ percolate in the river).

Analytical monitoring of the percolates discharged from the lysimeters over the 18 months of operation showed that the percolate of the first month was almost always that most heavily loaded. Under these conditions, we considered that it corresponded to the "critical" period of the scenario and thus decided to focus our attention on it. The results of the physicochemical analyses of the percolate of the first month of each of the three sediments are presented in Table 4 .

Regarding the "substances" approach, the calculation of exposure concentrations vis-à-vis aquatic organisms was performed using the results of the chemical analysis of the percolates to which the dilution factor Fp mentioned above was applied. This provided the PEC (Table 4).

For the "matrix approach", the predicted exposure concentration is expressed in percentage of percolate in the river: $0.04 \%$.

\subsection{Characterisation of effects and risks}

The effects measured by the "Predicted No Effect Concentration" on organisms were characterised as a function of the "substances approach" (PNECmg/l) and the "matrix approach" (PNEC\%). The risk can be characterised by comparing the results with the "Predicted Environmental Concentration" (PEC).

5.2.1. Characterisation of the effects and risks as a function of the "substances approach"

The results of this procedure, and that of the risk quotient of the calculated (Q) for each substances and each of the 3 sediments are presented in Table 5.

For sediment 3 , the ecotoxicological risk was very high for the aquatic ecosystem mainly due to the strong concentrations of copper and TBT in the percolate, and then in the river. For the two other sediments, no ecotoxicological risk was observed under the conditions of the scenario, for the substances monitored. For these two sediments, copper was the pollutant for which the safety margin was lowest $(\mathrm{Q}=0.55$ and 0.68$)$.

5.2.2. Characterisation of effects and risks according to the "matrix approach"

5.2.2.1. Effect characterisation. Table 6 groups the results of the different bioassays performed on the percolates studied. After analysing the rules recommended by the ECB (European Chemicals Bureau) in the TGD (Technical Guidance Document for new notified substances), and given the wealth and type of bioassays selected (chronicity, trophic levels), the value of the extrapolation factor applied to the result of the most unfavourable ecotoxicity test for establishing the PNEC of

Table 4

Physicochemical analyses of percolates, and PEC of the 3 sediments.

\begin{tabular}{|c|c|c|c|c|c|c|}
\hline & \multicolumn{2}{|c|}{ Sediment 1} & \multicolumn{2}{|c|}{ Sediment 2} & \multicolumn{2}{|l|}{ Sediment 3} \\
\hline & Percolate & PEC & Percolate & PEC & Percolate & PEC \\
\hline $\mathrm{pH}$ & 7.0 & & 7.1 & & 12.4 & \\
\hline Conductivity $(\mu \mathrm{S} / \mathrm{cm})$ & 33,500 & & 37,700 & & 23,600 & \\
\hline RedOx potential $(\mathrm{mV})$ & 397 & & 367 & & 110 & \\
\hline $\mathrm{NH}_{4}^{+}(\mu \mathrm{g} / \mathrm{l})$ & 900 & 0.38 & 200 & 0.086 & 2170 & 0.93 \\
\hline Chlorides (mg/l) & 10,890 & 4.67 & 12,310 & 5.27 & 5842 & 2.50 \\
\hline \multicolumn{7}{|l|}{ Metals $(\mu \mathrm{g} / \mathrm{l})$} \\
\hline As & 4 & 0.0017 & 4 & 0.0017 & 4 & 0.0017 \\
\hline $\mathrm{Cd}$ & 1 & 0.0004 & 1 & 0.0004 & 1 & 0.0004 \\
\hline $\mathrm{Cr}$ & 1 & 0.0004 & 43 & 0.0184 & 194 & 0.0831 \\
\hline $\mathrm{Pb}$ & 137 & 0.0587 & 22 & 0.0094 & 22 & 0.0094 \\
\hline $\mathrm{Zn}$ & 3510 & 1.5045 & 2270 & 0.9729 & 36 & 0.0154 \\
\hline Sn & 4 & 0.0017 & 4 & 0.0017 & 4 & 0.0017 \\
\hline $\mathrm{Cu}$ & 515 & 0.2207 & 642 & 0.2751 & 18,800 & 8.05 \\
\hline $\mathrm{Ni}$ & 64 & 0.0274 & 2 & 0.0008 & 522 & 0.2237 \\
\hline TBT (ng Sn/l) & $<50$ & $<0.0214$ & $<50$ & $<0.0214$ & 118,600 & 50.83 \\
\hline \multicolumn{7}{|l|}{ PAHs (ng/l) } \\
\hline Fluoranthène & 5 & 0.0021 & 5 & 0.0021 & 7 & 0.0030 \\
\hline Phénanthrène & 5 & 0.0021 & 5 & 0.0021 & 36 & 0.0154 \\
\hline Pyrène & $<5$ & $<0.0021$ & $<5$ & $<0.0021$ & $<5$ & $<0.0021$ \\
\hline Acénaphtène & $<5$ & $<0.0021$ & $<5$ & $<0.0021$ & $<5$ & $<0.0021$ \\
\hline Benzo(b) fluoranthène & $<5$ & $<0.0021$ & $<5$ & $<0.0021$ & $<5$ & $<0.0021$ \\
\hline Benzo(g, h, i)pérylène & 5 & 0.0021 & $<5$ & 0.0021 & $<5$ & $<0.0021$ \\
\hline Naphtalène & $<50$ & $<0.0214$ & $<50$ & $<0.0214$ & 106 & 0.0454 \\
\hline Indénol(1,2,3-c,d)pyrène & $<5$ & $<0.0021$ & $<5$ & $<0.0021$ & $<5$ & $<0.0021$ \\
\hline Benzo(k)fluoranthène & $<5$ & $<0.0021$ & $<5$ & $<0.0021$ & $<5$ & $<0.0021$ \\
\hline Anthracène & 5 & 0.0021 & 5 & 0.0021 & 9 & 0.0038 \\
\hline Fluorène & 5 & 0.0021 & 5 & 0.0021 & 12 & 0.0051 \\
\hline Benzo(a) anthracène & $<5$ & $<0.0021$ & $<5$ & $<0.0021$ & $<5$ & $<0.0021$ \\
\hline Benzo(a) pyrène & $<5$ & $<0.0021$ & $<5$ & $<0.0021$ & $<5$ & $<0.0021$ \\
\hline
\end{tabular}


Table 5

PNEC and "Q" of sediment percolates as a function of the "substances approach".

\begin{tabular}{|c|c|c|c|c|}
\hline Substances & Aquatic PNEC & $\begin{array}{l}\mathrm{Q} \\
\text { Sediment } 1\end{array}$ & $\begin{array}{l}\text { Q } \\
\text { Sediment } 2\end{array}$ & $\begin{array}{l}\mathrm{Q} \\
\text { Sediment } 3\end{array}$ \\
\hline Chlorides (mg/l) & 230 & 0.020 & 0.023 & 0.011 \\
\hline $\mathrm{NH}_{4}^{+}(\mu \mathrm{g} / \mathrm{l})$ & 5 & 0.077 & 0.017 & 0.18 \\
\hline \multicolumn{5}{|l|}{ Metals $(\mu \mathrm{g} / \mathrm{l})$} \\
\hline As & 4.40 & $\ll 1$ & $\ll 1$ & $\ll 1$ \\
\hline $\mathrm{Cd}$ & 0.75 & $\ll 1$ & $\ll 1$ & $\ll 1$ \\
\hline $\mathrm{Cr}$ & 4.70 & $\ll 1$ & $\ll 1$ & $\ll 1$ \\
\hline $\mathrm{Pb}$ & 5.00 & $\ll 1$ & $\ll 1$ & $\ll 1$ \\
\hline $\mathrm{Zn}$ & 8.60 & 0.17 & 0.11 & 0.17 \\
\hline Sn & 2.70 & $\ll 1$ & $\ll 1$ & $\ll 1$ \\
\hline $\mathrm{Cu}$ & 0.40 & 0.55 & 0.68 & 20.1 \\
\hline $\mathrm{Ni}$ & 4.70 & $\ll 1$ & $\ll 1$ & 0.047 \\
\hline TBT(ng Sn/l) & 0.1 & 0.21 & 0.21 & 508 \\
\hline \multicolumn{5}{|l|}{ PAHs (ng/l) } \\
\hline Fluoranthene & 120.0 & $\ll 1$ & $\ll 1$ & $\ll 1$ \\
\hline Phénanthrene & 1340 & $\ll 1$ & $\ll 1$ & $\ll 1$ \\
\hline Pyrene & 12.0 & $\ll 1$ & $\ll 1$ & $\ll 1$ \\
\hline Acénaphtene & 3700 & $\ll 1$ & $\ll 1$ & $\ll 1$ \\
\hline Benzo(b) fluoranthene & 30 & $\ll 1$ & $\ll 1$ & $\ll 1$ \\
\hline Benzo(g, h, i)perylene & 1.6 & $\ll 1$ & $\ll 1$ & $\ll 1$ \\
\hline Naphtalene & 12,000 & $\ll 1$ & $\ll 1$ & $\ll 1$ \\
\hline Indenol(1,2,3 c,d)pyrene & 3.0 & $\ll 1$ & $\ll 1$ & $\ll 1$ \\
\hline Benzo(k)fluoranthene & 36.0 & $\ll 1$ & $\ll 1$ & $\ll 1$ \\
\hline Anthracene & 63.0 & $\ll 1$ & $\ll 1$ & $\ll 1$ \\
\hline Fluorene & 250.0 & $\ll 1$ & $\ll 1$ & $\ll 1$ \\
\hline Benzo(a) anthracene & 650.0 & $\ll 1$ & $\ll 1$ & $\ll 1$ \\
\hline Benzo(a) pyrene & 50.0 & $\ll 1$ & $\ll 1$ & $\ll 1$ \\
\hline
\end{tabular}

the ecosystem concerned was set at " 10 ". On this base, the PNEC obtained for each sediment tested was as follows:

- Sediment 1: PNEC $=1.0 / 10)=0.10 \%$

- Sediment 2: PNEC $=0.6 / 10)=0.06 \%$

- Sediment 3: PNEC $=0.13 / 10)=0.013 \%$

5.2.2.2. Risk characterisation. The risk quotient calculated for each of the three sediments tested was as follows:

- Sediment $1: \mathrm{Q}=\mathrm{PEC} / \mathrm{PNEC}=0.04 / 0.1=0.4$

- Sediment 2: $\mathrm{Q}=\mathrm{PEC} / \mathrm{PNEC}=0.04 / 0.06=0.3$

- Sediment 3: $\mathrm{Q}=\mathrm{PEC} / \mathrm{PNEC}=0.04 / 0.013=3.1$.

For the peripheral aquatic ecosystem, sediments 1 and 2 therefore presented little risk if deposited in under the conditions of the scenario established at the beginning of the study. However, the risk quotient of sediment 3 was 3.1, leading to the conclusion of a significant ecotoxicological risk for the surrounding aquatic ecosystem if the sediment were deposited under the conditions of the scenario established at the beginning of the study.

Table 6

Ecotoxicity of percolates of the 3 sediments studied.

\begin{tabular}{|c|c|c|c|c|c|}
\hline Organisms & Effects & Parameters & Sed 1 & Sed 2 & Sed 3 \\
\hline Vibrio fischeri & Luminescence & CE50 & $15 \%$ & $24 \%$ & $2.2 \%$ \\
\hline Daphnia magna & Mobility & CE50 & $\begin{array}{l}\text { Non } \\
\text { toxic }\end{array}$ & $\begin{array}{l}\text { Non } \\
\text { toxic }\end{array}$ & $0.5 \%$ \\
\hline Brachionus calicyflorus & Reproduction & CE20 & $1.0 \%$ & $0,6 \%$ & $0.14 \%$ \\
\hline $\begin{array}{l}\text { Pseudokirchneriella } \\
\text { subcapitata }\end{array}$ & $\begin{array}{l}\text { Population } \\
\text { growth }\end{array}$ & CE20 & $1.0 \%$ & $2 \%$ & $0.13 \%$ \\
\hline $\begin{array}{l}\text { Pseudokirchneriella } \\
\text { subcapitata }\end{array}$ & $\begin{array}{l}\text { Enzymatic } \\
\text { activity } \\
\text { (esterase) }\end{array}$ & $\begin{array}{l}\text { Significant } \\
\text { effect }\end{array}$ & $1.0 \%$ & $\begin{array}{l}\text { No } \\
\text { effect }\end{array}$ & $0.4 \%$ \\
\hline $\begin{array}{l}\text { Trout cell lines (RTG-W1 } \\
\text { and RTL-W1) }\end{array}$ & Cytotoxicity & $\begin{array}{l}\text { Significant } \\
\text { effect }\end{array}$ & $5 \%$ & $1 \%$ & $0.5 \%$ \\
\hline $\begin{array}{l}\text { Trout cell lines (RTG-W1 } \\
\text { and RTL-W1) }\end{array}$ & $\begin{array}{l}\text { Génotoxicity } \\
\text { (Comet assay) }\end{array}$ & $\begin{array}{l}\text { Significant } \\
\text { DNA damage }\end{array}$ & \multicolumn{3}{|c|}{ No effect } \\
\hline
\end{tabular}

\section{Discussion}

\subsection{The results obtained}

\subsubsection{Chemical analyses of percolates}

The chemical analyses of the percolates of the three dredged sediments tested are hardly comparable to existing data in the literature which, for the most part, concern only the analysis of total pollutant content (Alebic-Juretic, 2011; Bhosle et al., 2006; Blanca, 2008; Colacicco et al., 2010; Gschwend and Hites, 1981; Langston et al., 1987; Lepland et al., 2010; Romano et al., 2004; Saeki et al., 2007; Simpson et al., 1996). Regarding the analysis of the percolates, we mention in the paragraph dedicated to the results that the concentrations of pollutants were higher in the percolate of the first month. This type of behaviour is consistent with what has been observed in other studies on the leaching of inland sediments (Perrodin et al., 2006) and other types of polluted materials (Delolme et al., 2010; Larmet and Delolme, 2005; Perrodin et al., 2000; Quina et al., 2010). The concentrations of pollutants obtained in the percolate of the first month of each of the three sediments tested are, moreover, logical given the nature of the sediments and the physicochemical properties of the pollutants concerned, i.e. (i) a very high chloride content linked to the maritime origin of the sediments, (ii) a variable heavy metal content, that can be linked in particular with the potential $\mathrm{pH}$ and Redox values of the sediments (Baltpurvins et al., 1996; Barna et al., 1997; Ichikawa and Sato, 1973; Quina et al., 2009). In the case of sediment " 3 ", treated with hydraulic binders, and whose percolate $\mathrm{pH}$ exceeded 12, emphasis must be given to the very high amount of copper in solution, (iii) low content in PAHs, which are compounds hardly soluble in water, and (iv) the very marked presence of TBTs in the percolate of sediment " 3 ". This was certainly related, once again, to the destabilisation of the sediment matrix by the hydraulic binders used to treat the sediments (Loustau-Cazalet et al., 2010).

\subsubsection{Exposure concentrations for aquatic organisms}

For the "substances" approach the first observation is that the relative presence of each pollutant is the same as that of the percolates, since it was assumed that the transfer of the deposit to the river by 
runoff on the soil did not change the proportion of the different pollutants present. Given the dilution of the percolate in the river, the concentrations in pollutants generally appeared low, with the exception of copper and TBT in the case of sediment " 3 ". It is noteworthy that due to this dilution the concentrations in chlorides predicted in the river (in the region of several $\mathrm{mg} / \mathrm{l}$ ) were quite comparable to that which can be observed for inland surface waters. Regarding the "matrix" approach, we recall that the value of $0.04 \%$ calculated for the proportion of percolate in the receiving river corresponds to the maximum, taking into account the conservative hypotheses made at the beginning of the study (value during the low flow period of the river).

\subsubsection{Effect characterisation}

Regarding the PNEC established for the "substances" approach, the value recorded for TBTs ( $0.1 \mathrm{ng} \mathrm{Sn} / \mathrm{l})$ stood out, indicating the very high toxicity of this substances for aquatic organisms (INERIS, 2011). The results of the bioassays implemented in the framework of the "matrix" approach showed that those with Brachionus calicyflorus and Pseudokirchneriella subcapitata were the most sensitive, which is consistent with the fact that they were chronic assays and also with the observations made in other studies using the same or similar batteries of bioassays (Angerville, 2009; Boillot et al., 2008). The EC20, EC50, and NOEC values obtained provide a relatively similar ecotoxicity profile between sediments "1" and "2", apart from esterase activity. However, the same values are 5 to 10 times lower for the percolate of sediment " 3 ", showing that it is far more ecotoxic. This ecotoxicity of the percolate of sediment "3" not only reflects its very high $\mathrm{pH}$, but also its high copper and TBT contents, as both of the latter were present in quantities high enough to affect organisms (see previous paragraph). The ammonia present in these percolates in non ionised form $\left(\mathrm{NH}_{3}\right)$, due to the high $\mathrm{pH}$, may also contribute to this ecotoxicity. Indeed, it is known that the toxicity of non ionised ammonia $\left(\mathrm{NH}_{3}\right)$ is clearly higher than that of ionised ammonia $\left(\mathrm{NH}_{4}^{+}\right)$(ATSDR, 2004).

\subsubsection{Ecological risks}

All said and done, the "substances" and "matrix" approaches both conclude in the absence of risk for the aquatic ecosystem if the quarry is filled with sediments " 1 " and " 2 " under the conditions defined for the scenario. For sediment " 3 ", the two approaches appear to converge, as they both conclude that sediment " 3 " represents a high risk for the aquatic ecosystem. The "substances" approach shows that TBT and, to a lesser extent, copper, are probably the sources of the high ecotoxicity of this percolate and the ecological risk stemming from it.

\subsection{Regarding the methodology}

The assessment of exposure, whether by the "substances" approach or the "matrix" approach, greatly depends on the scenario's spatial and hydrological data (rainfall, surface and deposit height, orientation of the surface slope, etc.). In the case of a real project, these data must be collected with care to ensure the quality of the assessment. In the case of the present study, the initial choices regarding the definition of the scenario studied have a major impact on the result. Nonetheless, these choices were realistic in comparison to the situations that can be found in-the-field.

The assessment of the "substances" approach directly depends on the quality of the PNEC supplied by reference organisations and/or the quality of the EC20, EC50, NOEC values supplied by international databases. The assessment of effects by the "matrix" approach greatly depends on the organisms tested and the ecotoxicological parameters selected. Although the parameters in this study included growth, reproduction and genotoxic effects, they only concerned a small number of organisms which, in addition, were tested individually whereas in nature they interact with each other and with their environment. It is clear that this is a highly simplified representation of the ecosystem. Other authors have proposed more thorough batteries of bioassays to assess effects (Charissou et al., 2006), or worked with more representative models of ecosystems, such as microcosms and mesocosms (Clément and Cadier, 1998; Clément et al., 1996; Gustafsson et al., 2000; Kan et al., 2011). Nonetheless, these approaches are far more costly and are not always "economically acceptable" when implemented in-the-field. Finally, the "real" issue is to know whether the battery of bioassays selected leads to sufficient protection of the ecosystems concerned. Furthermore, studying the integrity of DNA is interesting in the framework of risk assessment, in so far as it can forewarn of long-term effects, both for the organisms exposed and their offspring, via modifications of gene structure or expression (Anderson and Wild, 1994; Bickham et al., 2000; Depledge, 1996; Devaux et al., 1998; Larno et al., 2001; Würgler and Kramers, 1992). In the case of the present study, measuring the potential genotoxicity of matrixes measured using fish cell models constitutes a fairly novel approach which, despite the numerous validation steps required, could provide a simple tool in the future capable of assessing genotoxicity in a eukaryote cell model in the batteries of bioassays used to assess ecotoxicological risks.

The quotient method chosen to calculate and express risks is fast and well-suited for communicating results. However, it is a rather cursory means of characterising risks as it relies on several simplifications: (i) effects and exposure are both synthesised in one value, which can obscure conceptual biases; (ii) it does not readily take indirect effects into account. Other risk characterisation methods can be used in certain contexts (Babut and Perrodin, 2001; US EPA, 1998): (i) qualitative methods that characterise risk in two or three categories, for example, strong/weak/average, usually on the basis of expert opinion (Rivière, 1998). They are used for comparative approaches (e.g., two types of contamination), (ii) methods incorporating the entire pollutant/response relation, making it possible to estimate the level of risk associated with a given exposure level. These methods are especially useful for testing several risk reduction options, or when different exposure (as a function of time or geographical region) and/or effect (chronic/acute) concentrations exist (Klaine et al., 1996; Solomon et al., 1996).

\section{Conclusion}

This study showed that it is possible to assess risks for peripheral aquatic ecosystems caused by a deposit of dredged seaport sediments in a quarry, by using relatively accessible and mostly standardised ecotoxicological investigation methods. The method proposed here, which combined "substances" and "matrix" approaches, showed its efficiency for the three sediments tested: the "substances" approach showed that TBT, and to a lesser extent, copper, were probably the sources of a large proportion of the ecotoxicological risk, whereas the "matrix" approach provided a more realistic assessment, due in particular to the toxicity linked to the $\mathrm{pH}$ of the matrix, the inclusion of all the substances present in the percolate (including those not analysed), and the ecotoxicological interactions between substances liable to spur synergetic or antagonistic phenomena (Altenburger et al., 2000; Calamari and Alabaster, 1980; Deneer, 2000; Hermens and Leeuwangh, 1982; Vighi et al., 2003; Walter et al., 2002; Warne, 2003; Warne and Hawker, 1995).

Other ecological risk assessment approaches related to sediment deposits have been proposed, notably for inland sediments (USACE, 1998a, 1998b). The aim of our approach, adapted to marine sediments and combining two complementary approaches, was to improve understanding of the global process leading to ecotoxicological risk and the realism of the assessment in view to optimising decision-making at management level.

For all that, the methodology presented can, and must, undergo further improvement in several directions to permit its operational integration in procedures defined by organisations in charge of managing 
sediments. This validation will require in situ studies of aquatic communities performed simultaneously and comparatively with the chemical analyses and ecotoxicity tests included in our methodology, in order to verify the predictive nature of the assessment performed. It will also be advisable to check whether the battery of bioassays selected can be reduced or else must be completed. When considering this point, it must be borne in mind that reducing the number of biological responses by reducing the number of tests will lead to increasing the imprecision of ecotoxicity results, thereby augmenting the uncertainty relating to the characterisation of the risk due to the need to raise the number of applicable safety factors. Consequently, the gains made on the one hand could be detrimental to subsequent decision-making on the other. What is more, the works intended to improve the final phase of risk characterisation, currently based only on the quotient method, and to strengthen the expression of the results with the associated uncertainty, must be carried out to ensure optimal utilisation of the tool developed.

Lastly, it will be necessary to complete the investigations performed by studying the ecological risks linked to the two potential indirect phenomena not taken into account in the methodology presented: (i) the bioaccumulation and biomagnification of the pollutants in the organisms and trophic chains; and (ii) the potential eutrophication of rivers linked to the discharge of nutritive substances, in particular phosphates.

\section{Acknowledgements}

We thank all the teams that participated in the "SEDIGEST" research programme focusing on the assessment of ecological risks linked to filling-in coastal quarries with treated, dredged seaport sediments, and which belonged to the following organisations: ENTPE, INSA de Lyon, BRGM, INSAVALOR, INERIS, IN VIVO Environment, CETMEF, CG 83, CG 29 and EEDEMS. The details of all the participants in the programme can be consulted on the internet site www.sedigest.org. We also thank the French National Research Agency (ANR) and the "AXELERA", "Mer PACA" and "Mer Bretagne" clusters respectively for their financial assistance and the labelling assigned to the SEDIGEST project.

\section{References}

Altenburger R, Backhaus T, Boedeker W, Faust M, Scholze M, Grimme LH. Predictability of the toxicity of multiple chemical mixtures to Vibrio fischeri: mixtures composed of similarly acting chemicals. Environ Toxicol Chem 2000;19:2341-7.

Alebic-Juretic A. Polycyclic aromatic hydrocarbons in marine sediments from the Rijeka Bay area, Northern Adriatic, Croatia. Mar Pollut Bull 2011;62:863-9.

Andersen HV, Kjølholt J, Poll C, Dahl S, Stuer-Lauridsen F, Pedersen F, et al. Environmental risk assessment of surface water and sediments in Copenhagen harbour. Water Sci Technol 1998;37:263-72.

Anderson SL, Wild GC. Linking genotoxic responses and reproductive success in ecotoxicology. Environ Health Perspect 1994;102:9-12.

Andrén C, Eklund B, Gravenfors E, Kukulska Z, Tarkpea M. A multivariate biological and chemical characterization of industrial effluents connected to municipal sewage treatment plants. Environ Toxicol Chem 1998;17:228-33.

Angerville R. Évaluation des risques écotoxicologiques liés au déversement de Rejets Urbains par Temps de Pluie (RUTP) dans les cours d'eau : application à une ville française et à une ville haïtienne. PhD INSA de Lyon/ENTPE, Villeurbanne, France, 2009, p. 485.

ATSDR. Toxicological profiles for ammonia. Atlanta, GA: Agency for Toxic Substances and Disease Registry: 2004 U.S Department of Health and Human Services, Public Health Services http://www.atsdr.cdc.gov/toxpro2.html.

Babut M, Perrodin Y. Évaluation écotoxicologique de matériaux de dragage - (1) présentation et justification de la démarche. Cemagref, ENTPE, VNF, Centre d'Etudes Techniques Maritimes et Fluviales; 2001. p. 47.

Babut M, Perrodin Y, Bray M, Clément B, Delolme C, Devaux A, et al. Évaluation des risques écologiques causés par des matériaux de dragage: proposition d'une approche adaptée aux dépôts en gravière en eau. Rev Sci Eau 2002;15:615-39.

Baltpurvins KA, Burns RC, Lawrance GA. Heavy metals in wastewater: modelling the hydroxide precipitation of copper(II) from wastewater using lime as the precipitant. Waste Manag 1996;16:717-25.

Barthet L, Durrieu C, Kaibouchi S, Perrodin Y. Contribution à l'évaluation de l'impact sur les écosystèmes aquatiques de la valorisation en BTP de mâchefers d'incinération d'ordures ménagères (MIOM). Déchets, Sciences et Techniques : la revue Francophone d'Ecologie Industrielle 2003;30:16-9.

Barna R, Sanchez F, Moszkowicz P, Méhu J. Leaching behavior of pollutants in stabilized/solidified wastes. J Hazard Mater 1997;52:287-310.
Bhosle NB, Garg A, Harji R, Jadhav S, Sawant SS, Krishnamurthy V, et al. Butyltins in the sediments of Kochi and Mumbai harbours, west coast of India. Environ Int 2006;32:252-8.

Bickham JW, Sandhu S, Hebert PDN, Chiki L, Athwal R. Effects of chemical contaminants on genetic diversity in natural populations: implications for biomonitoring and ecotoxicology. Mutat Res 2000;463:33-51.

Blanca A-L. Environmental levels, toxicity and human exposure to tributyltin (TBT)contaminated marine environment. A review. Environ Int 2008;34:292-308.

Bliss Cl. The toxicity of poisons applied jointly. Ann Appl Biol 1939;26:585-615.

Boillot C, Angerville R, Panouillères M, Perrodin Y. Ecotoxicological risk assessment of hospital wastewater discharge: characterization of combined effect due to binary mixtures of three surfactants and three disinfectants towards Daphnia magna (Poster). 17th SETAC Europe, Porto (Portugal); 2007.

Boillot C, Bazin C, Tissot-Guerraz F, Droguet J, Perraud M, Cetre JC, et al. Daily physicochemical, microbiological and ecotoxicological fluctuations of a hospital effluent according to technical and care activities. Sci Total Environ 2008;403: 113-29.

Boillot C, Perrodin Y. Joint-action ecotoxicity of binary mixtures of glutaraldehyde and surfactants used in hospital: use of TI model and isoblogram representation. Ecotoxicol Environ Saf 2008;71:252-9.

Calamari D, Alabaster JS. An approach to theoretical models in evaluating the effects of mixtures of toxicants in the aquatic environment. Chemosphere 1980;9:533-8.

CEAEQ. Procédure d'évaluation des risques écotoxicologiques pour la réhabilitation des terrains contaminés. Québec: Centre d'Expertise en Analyse Environnementale du Québec; 1998. 139 pp.

CETMEF. Évaluation écotoxicologique de sédiments contaminés ou de matériaux de dragage. Centre d'Étude Techniques Maritimes Et Fluviale; 2001. p. 12.

Charissou AM, Jourdain MJ, Pandard P, Poulsen V, Devillers J, Férard JF, et al. Démarche optimale de sélection de batterie de bioessais pour l'évaluation écotoxicologique des milieux complexes. Synthèse bibliographique. Tech Sci Meth 2006;5:101-10.

Chatain V, Delolme C, Borschneck D, Giroud N, Thévenin L, Loustau-Cazalet M, et al. Assessment of the potential mobilization of inorganic contaminants in a French harbor sediment. Proceedings of the VIIth International Conference on Sustainable Management of Waste and Recycled Materials in Construction (WASCON 2009), Lyon, France, June 3-5 2009; 2009. 4 pp.

Clément B, Cadier C. Development of a new laboratory freshwater/sediment microcosm test. Ecotoxicology 1998;7:279-90.

Clément B, Persoone G, Colin J, Du-Delepierre A. Estimation of the hazard of landfills through toxicity testing of leachates. I. Determination of leachate toxicity with a battery of acute tests. Chemosphere 1996;33:2303-20.

Clément B, Vaille G, Moretto R, Vernus E, Abdelghafour M. Effects of a physico-chemical treatment of a dredged sediment on its ecotoxicity after discharge in laboratory gravel pit microcosms. J Hazard Mater 2009;175:205-15.

Colacicco A, De Gioannis G, Muntoni A, Pettinao E, Polettini A, Pomi R. Enhanced electrokinetic treatment of marine sediments contaminated by heavy metals and PAHs. Chemosphere 2010;81:46-56.

Davoren M, Fogarty AM. A test battery for the ecotoxicological evaluation of the agrichemical Environ. Ecotoxicol Environ Saf 2004;59:116-22.

Davoren M, Ní Shúilleabháin S, Hartl MGJ, Sheehan D, O'Brien NM, O'Halloran J, et al. Assessing the potential of fish cell lines as tools for the cytotoxicity testing of estuarine sediment aqueous elutriates. Toxicol In Vitro 2005a;19:421-31.

Davoren M, Ni Shúilleabháin S, O'Halloran J, Hartl MGJ, Sheehan D, O'Brien NM, et al. A test battery approach for the ecotoxicological evaluation of estuarine sediments. Ecotoxicology 2005b;14:741-55.

Dayeh VR, Bols NC, Shchirmer C. The use of fish-derived cell lines for investigation of environmental contaminants. Curr Protoc Toxicol 2003:151-7.

Delolme C, Larmet H, Vyas G, Angulo-Jaramillo R. Study and modeling of the stormwater pollutants transfer in urban soils: a lysimeter experiment. Ecotron and lysimeters, key tools for studying terrestrial ecosystem responses to global change, to pollutants, and the ecological engineering, 29-31 Mars 2010, Nancy, France; 2010.

Deneer JW. Toxicity of mixtures of pesticides in aquatic systems. Pest Manag Sci 2000;56:516-20.

Depledge MH. Genetic ecotoxicology: an overview. J Exp Mar Biol Ecol 1996;200: 57-66.

Devaux A, Flammarion P, Bernardon V, Garric J, Monod G. Monitoring of the chemical pollution of the river Rhône through measurement of DNA damage and cytochrome P4501A induction in chub (Leuciscus cephalus). Mar Environ Res 1998;46:257-62.

ECB. Technical Guidance Document (TGD) in support of Commission Directive 93/67/EEC on Risk Assessment for new notified substances, Commission Regulation (EC) No 1488/94 on Risk Assessment for existing substances and Directive 98/8/EC of the European Parliament and of the Council concerning the placing of biocidal products on the market. Ispra (Italy): European Chemical Bureau; 2003. p. 1044.

Emmanuel E, Perrodin Y, Keck G, Blanchard JM, Vermande P. Ecotoxicological risk assessment of hospital wastewater: a proposed framework for raw effluents discharging into urban sewer network. J Hazard Mater 2005;117:1-11.

Environment Agency of United Kingdoms. Ecological risk assessment, a public consultation on a frame work and methods for assessing harm to ecosystems from contaminants soil. Bristol (UK): Environment Agency of United Kingdoms; 2003. p. 104.

Feron VJ, Groten JP. Toxicological evaluation of chemical mixtures. Food Chem Toxicol 2002;40:825-39.

Grosdemange D, Leveque F, Drousie D, Aqua JL, Méhu J, Bazin C. The SEDIMARD project: presentation and results. International Symposium on Sédiment Management I2SM, Lille; 2008. p. 181-6. 
Gschwend PM, Hites RA. Fluxes of polycyclic aromatic hydrocarbons to marine and lacustrine sediments in the northeastern United States. Geochim Cosmochim Acta 1981;45:2359-67.

Gustafsson M, Dahl I, Blanck H, Hall P, Molander S, Nordberg K. Benthic foraminiferal tolerance to Tri-n-butyltin (TBT) pollution in an experimental mesocosm. Mar Pollut Bull 2000;40:1072-5.

Hayet A. Variabilité des méthodologies d'évaluation des risques écologiques : conséquences et perspectives d'améliorations. Mémoire de master recherche en ingénierie de la santé. Mention Santé - Environnement, 2. Institut Lillois d'Ingénierie de la Santé, Université de Lille; 2006. p. 95

Hermens J, Canton H, Janssen P, De Jong R. Quantitative structure-activity relationships and toxicity studies of mixtures of chemicals with anaesthetic potency: acute lethal and sublethal toxicity to Daphnia magna. Aquat Toxicol 1984;5:143-54.

Hermens JLM, Leeuwangh P. Joint toxicity of chemicals to Guppy (Poecilia reticulata). Ecotoxicol Environ Saf 1982;6:302-10.

Ichikawa F, Sato T. Amphoteric character of cadmium hydroxide and its solubility in alkaline solution. J Inorg Nucl Chem 1973;35:2592-4.

IFREMER. Dredging and marine environment. pp 20 http://envlit.ifremer.fr/var/envlit/ storage/documents/dossiers/bioevaluation/site/index.htm 2001.

INERIS. Fiche de données toxicologiques et environmentales des substances chimiques. 2006. INERIS; 2011. p. 66.

Isidori M, Lavorgna M, Nardelli A, Parrella A. Toxicity identification evaluation of leachates from municipal solid waste landfills: a multispecies approach. Chemosphere 2003;52:85-94.

Juvonen R, Martikainen E, Schultz E, Joutti A, Ahtiainen J, Lehtokari M. A battery of toxicity tests as indicators of decontamination in composting oily waste. Ecotoxicol Environ Saf 2000;47:156-66.

Kan J, Wang Y, Obraztsova A, Rosen G, Leather J, Scheckel KG, et al. Marine microbial community response to inorganic and organic sediment amendments in laboratory mesocosms. Ecotoxicol Environ Saf 2011;74:1931-41.

Kienzler A, Tronchere X, Devaux A, Bony S. Assessment of RTG-W1, RTL-W1, and PLHC1 fish cell lines for genotoxicity testing of environmental pollutants by means of a Fpg-modified comet assay. Toxicol In Vitro 2012;26:500-10.

Kim Y, Choi K, Jung J, Park S, Kim P-G, Park J. Aquatic toxicity of acetaminophen, carbamazepine, cimetidine, diltiazem and six major sulfonamides, and their potential ecological risks in Korea. Environ Int 2007;33:370-5.

Klaine SJ, Cobb GP, Dickerson RL, Dixon KR, Kendall RJ, Smith EE, et al. An ecological risk assessment for the use of the biocide, dibromonitrilopropionamide (DBNPA), in industrial cooling systems. Environ Toxicol Chem 1996;15:21-30.

Kocan RM, Sabo KM, Landolt ML. Cytotoxicity/genotoxicity: the application of cell culture techniques to the measurement of marine sediment pollution. Aquat Toxicol 1985;6:165-77.

Langston WJ, Burt GR, Mingjiang Z. Tin and organotin in water, sediments, and benthic organisms of Poole Harbour. Mar Pollut Bull 1987;18:634-9.

Larmet H, Delolme C. Facilitated transport of metals and bacteria into two infiltration basins in Lyon (France) under changing hydrological conditions: soil column study. The 10th "International Conference on Urban Drainage", Copenhagen (Danemark), du 21 au 26 août 2005; 2005. pp. CD ROM.

Larno V, Laroche J, Launey S, Flammarion P, Devaux A. Responses of chub (Leuciscus cephalus) populations to chemical stress, assessed by genetic markers, DNA damage and cytochrome P4501A induction. Ecotoxicology 2001;10:145-58.

Lau MM-m, Rootham RC, Bradley GC. A strategy for the management of contaminated dredged sediment in Hong Kong. J Environ Manage 1993;38:99-114.

Lepland A, Andersen TrJ, Lepland A, Arp HPH, Alve E, Breedveld GD, et al. Sedimentation and chronology of heavy metal pollution in Oslo harbor, Norway. Mar Pollut Bull 2010;60:1512-22.

Liliburne L, Phillips C. Risk assessment for contaminated sites in New Zealand. http:// contamsites.landcareresearch.co.nz 2011.

Lin Z, Du J, Yin K. Mechanism of concentration addition toxicity: they are different for nonpolar narcotic chemicals, polar narcotic chemicals and reactive chemicals. Chemosphere 2004;54:1691-701.

Loustau-Cazalet M, Chatain V, Brauer C, Blanc D, Delolme C, Borschneck D. Comportement et mobilisation potentielle de polluants inorganiques présents dans un sédiment marin traité à la chaux vive et aux liants hydrauliques. Colloque Eau, Déchets et Développement Durable, 28-31 mars 2010, Alexandrie, Egypte. https://docs.google. com/file/d/0B8xwB3OB-7F1MzhiNTUwMDUtNDBjMS00ZjhiLTg0NDUtM2VhMzE3Yj VmYmZm/edit.

Mamindy-Pajany Y, Libralato G, Roméo M, Hurel C, Losso C, Ghirardini AV, et al. Ecotoxicological evaluation of Mediterranean dredged sediment ports based on elutriates with oyster embryotoxicity tests after composting process. Water Res 2009;44: 1986-94.

MEEDDAT. Circulaire du 04/07/08 relative à la procédure concernant la gestion des sédiments lors de travaux ou d'opérations impliquant des dragages ou curages maritimes et fluviaux. BO du MEEDDAT n 2008/15 (France); 2008.

Naudin S, Garric J, Vindimian E, Bray M, Migeon B, Vollat B, et al. Influence of the sample preservation mode to assess the chronic toxicity of an industrial effluent. Ecotoxicol Environ Saf 1995;30:54-62.

Pandard P, Devillers J, Charissou A-M, Poulsen V, Jourdain M-J, Ferard J-F, et al. Selecting a battery of bioassays for ecotoxicological characterization of wastes. Sci Total Environ 2006;363:114-25.
Perrodin Y, Babut M, Bedell JP, Bray M, Clement B, Delolme C, et al. Assessment of ecotoxicological risks related to depositing dredged materials from canals in northern France on soil. Environ Int 2006;32:804-14.

Perrodin Y, Boillot C, Angerville R, Donguy G, Emmanuel E. Ecological risk assessment of urban and industrial systems: a review. Sci Total Environ 2011;409: 5162-76.

Perrodin Y, Grelier-Volatier L, Barna R, Gobbey A. Assessment of the ecocompatibility of waste disposal or waste use scenarios: towards the elaboration and implementation of a comprehensive methodology. Waste Manag Ser 2000;1:504-12.

Persoone G, Marsalek B, Blinova I, Torokne A, Zarina D, Manusadzianas L, et al. A practical and user-friendly toxicity classification system with microbiotests for natural waters and wastewaters. Environ Toxicol 2003;18:395-402.

Quina MJ, Bordado JoCM, Quinta-Ferreira RM. The influence of $\mathrm{pH}$ on the leaching behaviour of inorganic components from municipal solid waste APC residues. Waste Manag 2009;29:2483-93.

Quina MJ, Bordado JoCM, Quinta-Ferreira RM. Percolation and batch leaching tests to assess release of inorganic pollutants from municipal solid waste incinerator residues. Waste Manag 2010;31:236-45.

Radix P, Léonard M, Papantoniou C, Roman G, Saouter E, Gallotti-Schmitt S, et al. Comparison of four chronic toxicity tests using algae, bacteria, and invertebrates assessed with sixteen chemicals. Ecotoxicol Environ Saf 2000;47:186-94.

RECORD. Évaluation et acceptabilité des risques environnementaux. Méthodes d'évaluation, analyse comparativeEtude sociologique des représentations des risques et synthèse bibliographique; 2006. p. 227.

Ren S, Frymier PD. Use of multidimensional scaling in the selection of wastewater toxicity test battery components. Water Res 2003;37:1655-61.

Rivière JL. Évaluation du risque écologique des sols pollués. Paris: Tec \& Doc Lavoisier; 1998.

Rojícková-Padrtová R, MarIsálek B, Holoubek I. Evaluation of alternative and standard toxicity assays for screening of environmental samples: selection of an optimal test battery. Chemosphere 1998;37:495-507.

Romano E, Ausili A, Zharova N, Celia Magno M, Pavoni B, Gabellini M. Marine sediment contamination of an industrial site at Port of Bagnoli, Gulf of Naples, Southern Italy. Mar Pollut Bull 2004;49:487-95.

Saeki K, Nabeshima A, Kunito T, Oshima Y. The stability of butyltin compounds in a dredged heavily-contaminated sediment. Chemosphere 2007;68:1114-9.

Schaefer M. Assessing 2,4,6-trinitrotoluene (TNT)-contaminated soil using three different earthworm test methods. Ecotoxicol Environ Saf 2004;57:74-80.

SEDIGEST. Research Program of the French Agency of Research. http://www.sedigest org/2011.

Simpson CD, Mosi AA, Cullen WR, Reimer KJ. Composition and distribution of polycyclic aromatic hydrocarbon contamination in surficial marine sediments from Kitimat Harbor, Canada. Sci Total Environ 1996;181:265-78.

Solomon KR, Baker DB, Richards RP, Dixon KR, Klaine SJ, La Point TW, et al. Ecological risk assessment of atrazine in North American surface waters, 15. ; 1996. p. 31-76

Srut M, Traven L, Stambuk A, Kralj S, Zaja R, Micovic V, et al. Genotoxicity of marine sediments in the fish hepatoma cell line PLHC-1 as assessed by the Comet assay. Toxicol In Vitro 2010;25:308-14.

Suter GW. Environmental risk assessment. Chelsea: Lewis Publishers; 1993.

Theodorakis CW. Integration of genotoxic and population genetic endpoints in biomonitoring and risk assessment. Ecotoxicology 2001;10:245-56.

US-EPA. Framework for ecological risk assessment. Washington, DC: risk assessment forum. U.S. Environmental Agency; 1992. p. 161. EPA/630/R-92/001.

US-EPA. Integrated Risk Information System (IRIS). http://www.epa.gov/IRIS/2011.

US EPA. Guidelines for ecological risk assessment. Washington: United States Environmental Protection Agency; 1998. p. 188.

USACE U-E. Assessment of dredged material proposed for discharge in waters of the United States. Testing manual Report. Washington, D.C., USA: U.S. Environment Protection Agency-U.S. Army Corps of Engineers; 1998a. EPA-823/B-98/004.

USACE U-E. Great Lakes dredged material testing and assessment manual. Report. U.S Environmental Protection Agency/U.S. Army Corps of Engineers; 1998b.62.

Vighi M, Finizio A, Altenburger R, Walter H, Arrhenius A, Blanck H, et al. Water quality objectives for mixtures of toxic chemicals: problems and perspectives. Ecotoxico Environ Saf 2003;54:139-50.

Walter H, Consolaro F, Gramatica P. Mixture toxicity of priority pollutants at No Observed Effect Concentration (NOECs). Ecotoxicology 2002:299-310.

Warne MSJ. A review of the ecotoxicity of mixtures, approaches to, and recommendation for, their management. In: Langley A, Gilbey M, Kennedy B, editors. Fifth national workshop on the assessment of site contamination. Adelaide: EPHC - NEPC - en Health; 2003. p. 253-76.

Warne MSJ, Hawker DW. The number of components in a mixture determines whether synergistic and antagonistic or additive toxicity predominate: the funnel hypothesis. Ecotoxicol Environ Saf 1995;31:23-8.

Wong YS, Tam NFY, Lau PS, Xue XZ. The toxicity of marine sediments in Victoria Harbour Hong Kong. Mar Pollut Bull 1995;31:464-70.

Würgler FE, Kramers PGN. Environmental effects of genotoxins (eco-genotoxicology). Mutagenesis 1992;7:321-7. 